\title{
Received 28.03.2018 \\ Contents of selected macronutrients in bottom sediments of two water reservoirs and assessment of their suitability for natural use
}

\author{
Anna WÓJCIKOWSKA-KAPUSTA ${ }^{\text {BDEF } \bowtie}$, Halina SMAL ${ }^{\text {ABD }}$, \\ Sławomir LIGEZZA ${ }^{\mathrm{C}}$
}

\begin{abstract}
University of Life Sciences in Lublin, Institute of Soil Science, Environment Engineering and Management, ul. Leszczyńskiego 7, 20-069 Lublin, Poland; e-mail: anna.kapusta@up.lublin.pl; halina.smal@up.lublin.pl; slawomir.ligeza@up.lublin.pl
\end{abstract}

For citation: Wójcikowska-Kapusta A., Smal H., Ligęza S. 2018. Contents of selected macronutrients in bottom sediments of two water reservoirs and assessment of their suitability for natural use. Journal of Water and Land Development. No. 38 p. 147-153. DOI: 10.2478/jwld-2018-0051.

\begin{abstract}
The purpose of the present study was to analyse the contents of calcium, magnesium, potassium, and sodium in bottom sediments of two water reservoirs. The chemical composition of the bottom sediments and the ratios between the studied macronutrients were assessed, taking into account the nutritional requirements of plants, to determine whether the sediments were suitable for use in natural/agricultural settings.

The study was conducted at two water reservoirs: the Brody Iłżeckie reservoir built on the Kamienna River in the Świętokrzyskie Province, and Zalew Zemborzycki, lake on the Bystrzyca River in the Lublin Province. Both bodies of water serve as flood water diversion and leisure facilities, and are also used, to a small extent, by the industry. They have a similar age and surface area. Bottom sediments were collected from the reservoirs a single time: 14 samples from Zalew Zemborzycki and 17 from Brody Iłżeckie. Samples were tested for total contents of $\mathrm{Ca}, \mathrm{Mg}, \mathrm{K}$, and $\mathrm{Na}$. The bottom sediments from Zalew Zemborzycki contained higher amounts of calcium, magnesium, and potassium than the material from Brody Iłżeckie. The values of ratios between $\mathrm{K}: \mathrm{Mg}$ and $\mathrm{K}:(\mathrm{Ca}+\mathrm{Mg})$ were similar for both reservoirs, and $\mathrm{Ca}: \mathrm{Mg}$ and $\mathrm{Ca}: \mathrm{K}$ were slightly more favourable for the sediments taken from Brody Iłżeckie.
\end{abstract}

Key words: bottom sediments, $\mathrm{Ca}, \mathrm{Mg}, \mathrm{K}, \mathrm{Na}$, natural use, water reservoirs

\section{INTRODUCTION}

Water reservoirs silt up with a varying intensity. After some time, however, most of them need to be desludged and restored [MADEYSKI, TARNAWSKI 2007; TrojanOWSKI, ANTONOWICZ 2005]. Sludge extracted from reservoir should be utilized, and the way it is used depends on its fertility and pollution. The chemical composition of bottom deposits of a water reservoir is influenced by the type of rocks that form the catchment, human activity [GAŁKA, WIATKOWSKI 2010], the way the catchment area is used, pollutants that enter surface waters [BOJAKOWSKA et al. 2006], the flow patterns, and the rate of water exchange [CHOIŃSKI et al. 2010].

Bottom sediments, if they meet the relevant requirements, can be used to fertilize light soils as well as to remediate degraded areas. Whether bottom sediments can be recycled in the natural environment/ agriculture is determined by their content of macronutrients, in particular available forms of phosphorus, potassium, and magnesium [GAŁKA, WIATKOWSKI 2010] as well as calcium. 


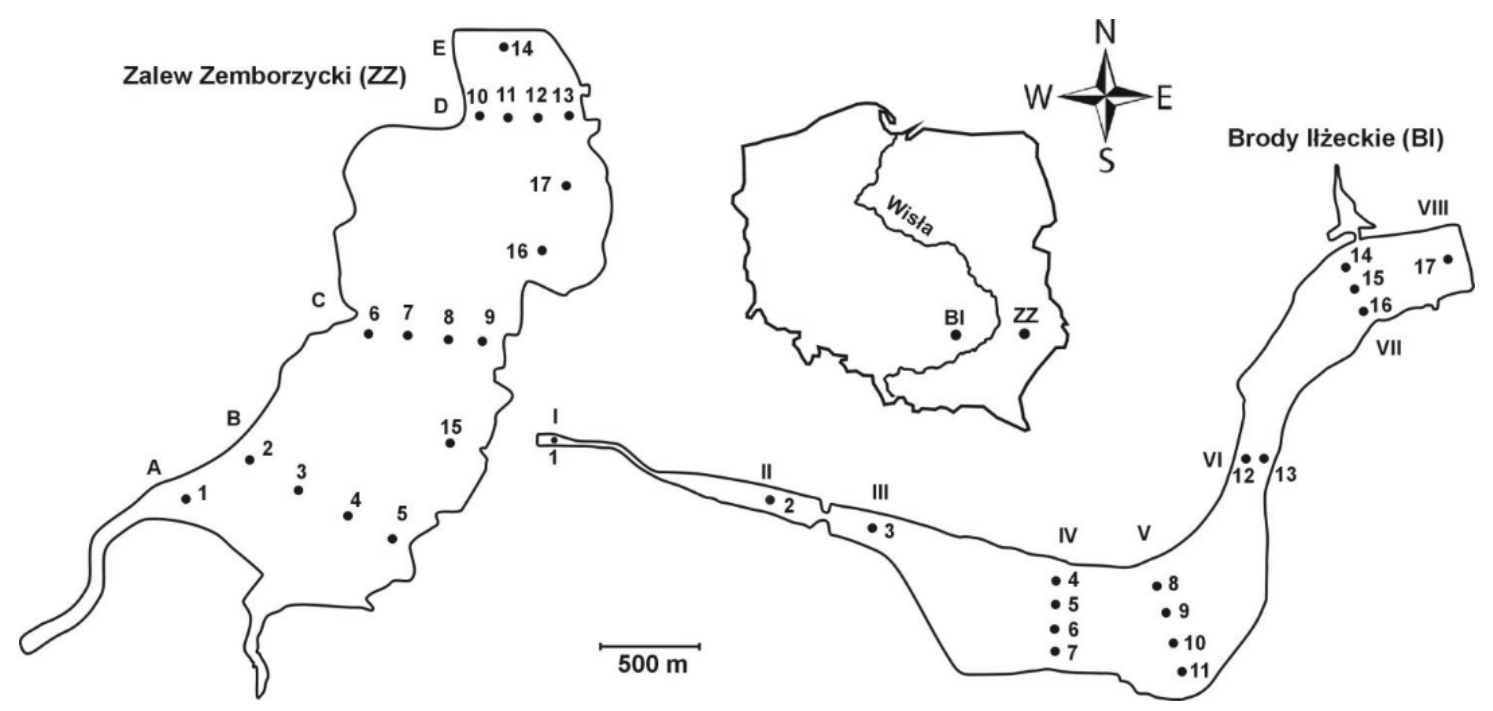

Fig. 1. Sediment sampling sites; source: SMAL et al. [2012], modified

The purpose of the present study was to analyse the contents of calcium, magnesium, potassium, and sodium in bottom sediments of two water reservoirs. The chemical composition of the bottom sediments and the ratios between the studied macronutrients were assessed, taking into account the nutritional requirements of plants, to determine whether the sediments were suitable for use in natural/agricultural purposes.

\section{MATERIAL AND METHODS}

The study was conducted in two water reservoirs: Zalew Zemborzycki (the Zemborzyce artificial reservoir) built in 1974 on the river Bystrzyca in the Lublin Province, and Brody Iłżeckie, a reservoir in the Świętokrzyskie Province, built on the Kamienna River in the years 1961-1965, and rebuilt in 1986. Both bodies of water serve as flood water diversion and leisure facilities, and are also used to a small extent by the industry. Zalew Zemborzycki covers an area of 278 ha, and Brody Iłżeckie, 203 ha.

Bottom sediments were collected once in the summer season: 14 samples from Zalew Zemborzycki and 17 from Brody Iłżeckie (Fig. 1). Samples were collected at designated transects and sites using $\mathrm{Ka}$ jak's core sampler. $5 \mathrm{dm}^{3}$ of liquid sediment was collected into polyethylene containers. The sediment samples were air-dried, homogenized, and passed through a $2 \mathrm{~mm}$ sieve.

The total contents of calcium, magnesium, potassium, and sodium were determined by ICP-AES using the Leeman PS 950 apparatus, following extraction of the sediment with a mixture of $\mathrm{HNO}_{3}$ and $\mathrm{HClO}_{4}$ $(5: 4 ; \mathrm{v} / \mathrm{v})$.

The results were analysed statistically using Statistica Statsoft 10 to obtain means, variation range maximum and minimum values, standard deviation, and correlation coefficients. The ratios of the analysed macronutrients were also calculated.

\section{RESULTS AND DISCUSSION}

The $\mathrm{pH}$ values of the bottom sediments collected from the examined water reservoirs were varied. In the Brody Iłżeckie reservoir, the $\mathrm{pH}$ values of the sediments, determined in water, ranged from 5.49 to 6.80 , whereas in Zalew Zemborzycki, they range from 6.85 to 7.33 [SMAL et al. 2012]. Sediment samples collected from the two reservoirs also had different contents of organic carbon. In Brody Iłżeckie, the content of $\mathrm{C}_{\text {org }}$ in the sediments was in the range of $0.78-49.80$ $\mathrm{g} \cdot \mathrm{kg}^{-1}$ with a mean of $20.44 \mathrm{~g} \cdot \mathrm{kg}^{-1}$. Samples collected from Zalew Zemborzycki had much higher $\mathrm{C}_{\text {org }}$ contents, ranging from 16.50 to $87.00 \mathrm{~g} \cdot \mathrm{kg}^{-1}$, with a mean of $41.38 \mathrm{~g} \mathrm{C}_{\text {org }} \cdot \mathrm{kg}^{-1}$ [SMAL et al. 2015].

The sediments from Brody Iłżeckie had low calcium content, in the range of $0.84-5.64 \mathrm{~g} \cdot \mathrm{kg}^{-1}$, mean $2.76 \mathrm{~g} \mathrm{Ca}^{-1} \mathrm{~kg}^{-1}$ (Tab. 1). Sediments collected at the outflow zone of the reservoir (transects VI and VII) were characterized by a higher content of this element than those sampled at sites located at the inflow of the Kamienna River (transects I-IV). The sediments from Zalew Zemborzycki contained over 15 times more calcium (a mean calcium content of $70.03 \mathrm{~g} \mathrm{Ca} \cdot \mathrm{kg}^{-1}$ ) than those from Brody Iłżeckie (Tab. 2). Calcium content in these sediments had a wide range of values (35.49 to $117.6 \mathrm{~g} \mathrm{Ca} \mathrm{kg}^{-1}$ ). The high calcium content in Zalew Zemborzycki sediments can be explained by the presence of loess soils in the catchment area, which are rich in carbonates [TURSKI et al. 1985]. The spatial distribution of calcium was similar in both reservoirs: lower Ca contents were recorded in the water inflow zone and higher contents were observed at the dam. The calcium content in bottom sediments from both reservoirs corresponded with the $\mathrm{pH}$ of these sediments [SMAL et al. 2012].

Calcium contents similar to those found in the sediments of Brody Iłżeckie were reported in a study by TROJANOWSKI and ANTONOWICZ [2005], who analysed the bottom sediments of Lake Dołgie Wielkie. 
Table 1. Contents of macronutrients in bottom sediments of the Brody Iłżeckie reservoir

\begin{tabular}{|c|c|c|c|c|c|c|c|c|}
\hline \multirow{2}{*}{ Number of sample } & $\mathrm{Ca}$ & $\mathrm{Mg}$ & K & $\mathrm{Na}$ & \multirow{2}{*}{$\mathrm{Ca}: \mathrm{Mg}$} & \multirow{2}{*}{$\mathrm{Ca}: \mathrm{K}$} & \multirow{2}{*}{$\mathrm{K}: \mathrm{Mg}$} & \multirow{2}{*}{$\mathrm{K}:(\mathrm{Ca}+\mathrm{Mg})$} \\
\hline & \multicolumn{4}{|c|}{$\mathrm{g} \cdot \mathrm{kg}^{-1}$} & & & & \\
\hline I1 & 2.30 & 0.26 & 0.43 & 0.088 & 8.85 & 5.35 & 1.65 & 0.17 \\
\hline II2 & 1.10 & 0.17 & 0.50 & 0.081 & 6.47 & 2.20 & 2.94 & 0.39 \\
\hline III3 & 2.36 & 0.84 & 1.21 & 0.142 & 2.81 & 1.95 & 1.44 & 0.38 \\
\hline Mean & 1.92 & 0.39 & 0.71 & 0.105 & 4.92 & 2.70 & 1.82 & 0.31 \\
\hline IV4 & 2.60 & 0.99 & 1.15 & 0.154 & 2.62 & 2.26 & 1.16 & 0.32 \\
\hline IV5 & 2.13 & 0.73 & 1.12 & 0.136 & 2.92 & 1.90 & 1.53 & 0.39 \\
\hline IV6 & 0.92 & 0.14 & 0.40 & 0.092 & 6.57 & 2.30 & 2.86 & 0.38 \\
\hline IV7 & 2.21 & 1.16 & 1.75 & 0.161 & 1.91 & 1.26 & 1.51 & 0.52 \\
\hline Mean & 1.96 & 0.75 & 1.10 & 0.136 & 2.61 & 1.78 & 1.47 & 0.41 \\
\hline V8 & 0.84 & 0.13 & 0.38 & 0.091 & 6.46 & 2.21 & 2.92 & 0.39 \\
\hline V9 & 2.55 & 1.56 & 2.23 & 0.180 & 1.63 & 1.14 & 1.43 & 0.54 \\
\hline V10 & 2.97 & 1.91 & 2.94 & 0.206 & 1.55 & 1.01 & 1.54 & 0.60 \\
\hline V11 & 1.97 & 0.68 & 1.04 & 0.118 & 2.90 & 1.89 & 1.53 & 0.39 \\
\hline Mean & 2.08 & 1.07 & 1.65 & 0.149 & 1.94 & 1.26 & 1.54 & 0.52 \\
\hline VI12 & 4.19 & 4.67 & 6.24 & 0.415 & 0.90 & 0.67 & 1.34 & 0.70 \\
\hline VI13 & 4.89 & 3.73 & 5.35 & 0.357 & 1.31 & 0.91 & 1.43 & 0.62 \\
\hline Mean & 4.54 & 4.20 & 5.80 & 0.386 & 1.08 & 0.78 & 1.38 & 0.66 \\
\hline VII14 & 5.22 & 3.60 & 5.63 & 0.338 & 1.45 & 0.93 & 0.56 & 0.64 \\
\hline VII15 & 5.69 & 3.35 & 4.51 & 0.330 & 1.70 & 1.26 & 1.35 & 0.50 \\
\hline VII16 & 2.06 & 1.56 & 2.14 & 0.195 & 1.32 & 0.96 & 1.37 & 0.59 \\
\hline Mean & 4.32 & 2.84 & 4.09 & 0.288 & 1.52 & 1.06 & 1.44 & 0.57 \\
\hline VIII17 & 3.00 & 2.10 & 2.78 & 0.214 & 1.43 & 1.08 & 1.32 & 0.54 \\
\hline Overall mean & 2.76 & 1.66 & 2.34 & 0.194 & 3.11 & 1.71 & 1.41 & 0.53 \\
\hline Minimum & 0.84 & 0.13 & 0.38 & 0.081 & 0.90 & 0.67 & 1.16 & 0.17 \\
\hline Maximum & 5.69 & 4.67 & 6.24 & 0.415 & 8.85 & 5.35 & 2.94 & 0.70 \\
\hline$S D$ & 1.54 & 1.44 & 1.96 & 0.100 & 3.41 & 1.08 & 0.65 & 0.13 \\
\hline$R S D(\%)$ & 55.80 & 86.75 & 83.76 & 51.55 & 109.65 & 63.16 & 12,76 & 24.53 \\
\hline
\end{tabular}

Explanations: $S D=$ standard deviation; $R S D=$ relative standard deviation.

Source: own study.

Table 2. Content of macronutrients in bottom sediments of Zalew Zemborzycki

\begin{tabular}{|c|c|c|c|c|c|c|c|c|}
\hline \multirow{2}{*}{ Number of sample } & $\mathrm{Ca}$ & $\mathrm{Mg}$ & $\mathrm{K}$ & $\mathrm{Na}$ & \multirow{2}{*}{$\mathrm{Ca}: \mathrm{Mg}$} & \multirow{2}{*}{$\mathrm{Ca}: \mathrm{K}$} & \multirow{2}{*}{$\mathrm{K}: \mathrm{Mg}$} & \multirow{2}{*}{$\mathrm{K}:(\mathrm{Ca}+\mathrm{Mg})$} \\
\hline & \multicolumn{4}{|c|}{$\mathrm{g} \cdot \mathrm{kg}^{-1}$} & & & & \\
\hline A1 & 43.19 & 1.54 & 1.95 & 0.181 & 28.05 & 22.15 & 1.27 & 0.04 \\
\hline B2 & 51.66 & 1.54 & 1.90 & 0.178 & 33.54 & 27.19 & 1.23 & 0.04 \\
\hline B3 & 66.85 & 1.82 & 2.19 & 0.199 & 36.73 & 30.52 & 1.20 & 0.03 \\
\hline B4 & 61.81 & 1.82 & 1.78 & 0.184 & 33.96 & 34.72 & 0.98 & 0.03 \\
\hline B5 & 74.20 & 1.70 & 1.60 & 0.181 & 43.65 & 46.37 & 0.94 & 0.02 \\
\hline Mean & 63.63 & 1.72 & 1.87 & 0.186 & 36.99 & 34.03 & 1.09 & 0.03 \\
\hline C6 & 35.49 & 1.26 & 1.50 & 0.145 & 28.17 & 23.66 & 1.19 & 0.03 \\
\hline $\mathrm{C} 7$ & 73.50 & 1.86 & 1.93 & 0.193 & 39.52 & 38.08 & 1.04 & 0.03 \\
\hline $\mathrm{C} 8$ & 54.46 & 1.02 & 1.09 & 0.142 & 53.39 & 49.96 & 1.07 & 0.02 \\
\hline C9 & 75.60 & 2.07 & 2.13 & 0.206 & 36.52 & 35.49 & 1.03 & 0.03 \\
\hline Mean & 59.76 & 1.55 & 1.66 & 0.172 & 38.55 & 36.00 & 1.07 & 0.03 \\
\hline D10 & 117.6 & 2.05 & 2.06 & 0.198 & 57.36 & 57.09 & 1.00 & 0.02 \\
\hline D11 & 78.40 & 1.97 & 1.95 & 0.193 & 39.80 & 40.20 & 0.99 & 0.02 \\
\hline D12 & 77.00 & 1.99 & 2.08 & 0.200 & 38.69 & 37.02 & 1.04 & 0.03 \\
\hline D13 & 75.60 & 2.00 & 2.10 & 0.204 & 37.80 & 36.00 & 1.05 & 0.03 \\
\hline Mean & 87.15 & 2.00 & 2.05 & 0.199 & 43.57 & 42.51 & 1.02 & 0.02 \\
\hline E14 & 74.20 & 2.22 & 2.24 & 0.208 & 33.42 & 33.12 & 1.01 & 0.03 \\
\hline Overall mean & 68.54 & 1.77 & 1.89 & 0.187 & 38.72 & 36.26 & 1.07 & 0.03 \\
\hline Minimum & 35.49 & 1.02 & 1.09 & 0.142 & 28.05 & 22.15 & 0.94 & 0.02 \\
\hline Maximum & 117.6 & 2.22 & 2.24 & 0.206 & 57.36 & 57.09 & 1.27 & 0.04 \\
\hline$S D$ & 19.67 & 0.33 & 0.31 & 0.02 & 8.0 & 10.1 & 0.12 & 0.007 \\
\hline$R S D(\%)$ & 28.70 & 18.64 & 16.40 & 10.70 & 20.66 & 27.85 & 11.21 & 23.33 \\
\hline
\end{tabular}

Explanations: $S D=$ standard deviation; $R S D=$ relative standard deviation.

Source: own study. 
Those authors claimed that the content was low compared to the contents of calcium in the sediments of other lakes of Western Pomerania. Also SKWIERAWSKI [2003], who studied bottom sediments of 10 water reservoirs in the Olsztyn Lake District, found that the deposits had varied contents of calcium, ranging from 0.2 to $192.8 \mathrm{~g} \mathrm{Ca} \cdot \mathrm{kg}^{-1}$.

In contrast to calcium, the mean content of magnesium was similar for the sediments of both reservoirs investigated in the present study. More varied magnesium content values were found in the sediments collected from Brody Iłżeckie, in which the minimum $\mathrm{Mg}$ content was $0.13 \mathrm{~g} \cdot \mathrm{kg}^{-1}$ and the maximum content was $4.67 \mathrm{~g} \cdot \mathrm{kg}^{-1}\left(S D=1.44 \mathrm{~g} \mathrm{Mg} \cdot \mathrm{kg}^{-1}\right)$. By comparison, sediments from Zalew Zemborzycki contained from 1.02 to $2.22 \mathrm{~g} \mathrm{Mg} \cdot \mathrm{kg}^{-1}$ of this metal $\left(S D=0.33 \mathrm{~g} \mathrm{Mg} \cdot \mathrm{kg}^{-1}\right)$. Similar magnesium contents were recorded by TROJANOWSKI and ANTONOWICZ [2005] in the bottom sediments of Lake Dołgie Wielkie. NIEDŹWIECKI et al. [2007] found considerably higher magnesium contents in the sediments of Lake Rusałka, and contents similar to those reported in this present study - in Lake Słoneczne.

Differences in the spatial distribution of magnesium content were observed only for the sediments of the Brody Iłżeckie reservoir. The highest contents of this metal were found in sediments collected in the central part of the narrowest section of this water body, while sediments in the water inflow zone contained the lowest quantities of this element. NIEDŹWIECKI et al. [2007] found similar relationships for sediments of two lakes located in Szczecin. The accumulation of magnesium was much larger in their central part than at the outflow. Such spatial distribution of magnesium can be explained by its accumulation in the sediments of the water bodies [GAŁKA, WIATKOWSKI 2010].

No such dependencies were found for sediments collected from different zones of Zalew Zemborzycki. Only a tendency for magnesium content to be higher in the outflow zone was noted. A similarly small variation in magnesium content has been observed by RAFAŁOWSKA and SOBCZYŃSKA-WÓJCIK [2014], who analysed bottom sediments from Pilwa Bay of Lake Dobskie. However, the content of this element in the sediments of Pilwa Bay was much higher than in Zalew Zemborzycki (8.11-9.46 g Mg.kg $\left.{ }^{-1} \mathrm{DM}\right)$.

The potassium content in the bottom sediments of the Brody Iłżeckie dam reservoir was in the range 0.38-6.24 $\mathrm{g} \mathrm{K}^{\mathrm{kgg}} \mathrm{kg}^{-1}$ (Tab. 1). Sediments abounding in potassium were found in sectors VI and VII (near the dam); the average potassium content in those sampling areas was 5.80 and $4.09 \mathrm{~g} \mathrm{~K} \cdot \mathrm{kg}^{-1}$, respectively. At the water inflow, the content of this element in the sediments was several times smaller.

Compared to the reservoir in Brody Iłżeckie, the sediments in Zalew Zemborzycki were characterized by a lower potassium content, ranging between 1.09 and $2.24 \mathrm{gK} \cdot \mathrm{kg}^{-1}$. The scatter of values was also much smaller, as evidenced by the standard deviation $\left(0.31 \mathrm{~g} \mathrm{~K} \mathrm{~kg}^{-1}\right)$. There were no differences in the spatial distribution of potassium in the sediments of Zalew Zemborzycki. In their study NIEDŹWIECKI et al. [2007] found that sediments in two Szczecin lakes were characterized by a much higher content of this element than found in the present study. SKWIERAWSKI [2003], in turn, found large variation in the potassium content $\left(0.3-12.1 \mathrm{~g} \mathrm{~K} \cdot \mathrm{kg}^{-1}\right)$ in the bottom sediments of small lake reservoirs in the Olsztyn Lake District.

The sodium content in the bottom sediments of the reservoirs investigated in the present study varied across samples. In Brody Iłżeckie, its content ranged from 0.081 to $0.415 \mathrm{~g} \mathrm{Na} \cdot \mathrm{kg}^{-1}$ and in Zalew Zemborzycki - from 0.142 to $0.206 \mathrm{~g} \mathrm{Na} \cdot \mathrm{kg}^{-1}$. As in the case of the other elements, spatial differences in the content of sodium in the sediments were observed only for Brody Iłżeckie, in which most of the sodium was accumulated in the sediments of the sectors located near the dam (Tab. 1, 2).

The concentrations (by overall mean) of the investigated micronutrients in bottom sediments of Brody Iłżeckie and Zalew Zemborzycki can be arranged in the following decreasing order: $\mathrm{Ca}>\mathrm{K}>$ $\mathrm{Mg}>\mathrm{Na}$. In both reservoirs, calcium was the dominant element, and the content of potassium was either higher than (Brody Iłżeckie) or similar to (Zalew Zemborzycki) the content of magnesium. To compare, in RAFAŁOWSKA and SOBCZYŃSKA-WÓJCIK's study [2014], these elements found in bottom sediments of Pilwa Bay formed the following order of concentrations $\mathrm{Ca}>\mathrm{Mg}>\mathrm{Na}>\mathrm{K}$. Similar results have been obtained by TARNAWSKI et al. [2012] for bottom sediments of Lake Chańcza, in which the concentrations of macronutrients were in the following order: $\mathrm{Ca}>\mathrm{Mg}>\mathrm{K}$.

Statistical analysis showed high correlation coefficients between $\mathrm{Mg}, \mathrm{K}$ and $\mathrm{Na}$ contents in the bottom sediments of both reservoirs (Tab. 3).

Table 3. Values of Pearson's correlation coefficients between macronutrients found in bottom sediments of Brody Iłżeckie and Zalew Zemborzycki reservoirs

\begin{tabular}{|c|c|c|c|}
\hline Macronutrient & $\mathrm{Mg}$ & $\mathrm{K}$ & $\mathrm{Na}$ \\
\hline \multicolumn{4}{|c|}{ Brody Ilżeckie reservoir $\boldsymbol{n}=\mathbf{1 7}$} \\
\hline $\mathrm{Ca}$ & $0.9023^{*}$ & $0.9033^{*}$ & $0.9057^{*}$ \\
\hline $\mathrm{Mg}$ & & $0.9941^{*}$ & $0.9973^{*}$ \\
\hline $\mathrm{K}$ & & $0.9910^{*}$ \\
\hline \multicolumn{3}{|c|}{ Zalew Zemborzycki reservoir $\boldsymbol{n}=\mathbf{1 4}$} \\
\hline $\mathrm{Ca}$ & $0.7078^{*}$ & 0.4612 & $0.6444^{*}$ \\
\hline $\mathrm{Mg}$ & & $0.8761^{*}$ & $0.9593^{*}$ \\
\hline $\mathrm{K}$ & & & $0.9276^{*}$ \\
\hline
\end{tabular}

Explanations: $n=$ number of sediment samples, * significant at $\alpha_{0.05}$. Source: own study.

In the bottom sediments of Brody Iłżeckie, in which the calcium content was small, a close correlation significant at $\alpha=0.05$ was found between the elements. In the case of Zalew Zemborzycki, no significant correlation was found between $\mathrm{Ca}$ and $\mathrm{K}$, and 
the correlations between $\mathrm{Ca}-\mathrm{Na}$ and $\mathrm{Ca}-\mathrm{Mg}$ were significant but weaker. High correlation coefficients between $\mathrm{Ca}$ and $\mathrm{Mg}$ as well as $\mathrm{Ca}$ and $\mathrm{K}$ in bottom sediments were also found by TARNAWSKI et al. [2012].

Water reservoirs silt up and become shallower with time, which means they have to be cleaned and restored. Silting leads to the formation of large quantities of bottom sediments, which should be properly utilized. How such sediments are used depends on their contents of nutrients and pollutants [BARAN et al. 2009; GAŁKA, WIATKOWSKI 2010; SAMMEL 2015]. The most viable and environmentally friendly method of recycling bottom deposits is to use them for reclamation or fertilization of light and acidic soils [BARAN et al. 2009; NIEDŹWIECKI et al. 2007; SAMMEL 2015; WiŚNIOWSKA-KIELIAN et al. 2012]. Ca:Mg, $\mathrm{Ca}: \mathrm{K}, \mathrm{K}: \mathrm{Mg}$, and $\mathrm{K}:(\mathrm{Ca}+\mathrm{Mg})$ mass ratios are important indicators of the ability of soils to supply plants with these elements, and so they may be used to indicate how bottom sediments should be used.

The Ca:Mg ratio in the sediments of the discussed reservoirs varied considerably across sampling points. The ratio was the highest (8.85) in the sediments collected from the water inflow zone of Brody Iłżeckie, and in the remaining sampling points, it ranged from 0.90 to 6.57 (Tab. 1). In Zalew Zemborzycki, the ratio was in a wide range between 28.05 and 57.09; the widest ratio was found in the sediments from sector D (Tab. 2). For optimal plant nutrition, the $\mathrm{Ca}: \mathrm{Mg}$ ratio in soil should not be higher than 5.0-7.5:1 [MERCIK 2004]. In the sediments from Brody Iłżeckie, this ratio was slightly more favourable compared to the sediments from Zalew Zemborzycki. In Polish soils, the $\mathrm{Ca}: \mathrm{Mg}$ ratio is on average 6.7 and ranges from 2 to 26 [FoTYMA et al. 1987]. The wide ratio of calcium to magnesium observed in the sediments from Zalew Zemborzycki results from the high $\mathrm{Ca}$ content in that material

In the bottom sediments of Brody Iłżeckie, the $\mathrm{Ca}: \mathrm{K}$ ratio ranged from 0.67 to 5.35 , and in those collected from Zalew Zemborzycki, it ranged from 22.15 to 57.09. In Brody Iłżeckie, the widest $\mathrm{Ca}: \mathrm{K}$ ratio was observed in samples of bottom sediments from the water inflow zone, whereas in Zalew Zemborzycki, in sediments from sector D (outflow). The optimal Ca:K ratio in soil is (10-15):1 [KIEPUL 2003]. In the sediments of Brody Iłżeckie, the discussed ratio was lower than optimal, but slightly more favourable than the very high ratio found in the sediments from Zalew Zemborzycki.

The best yield-increasing effect is obtained at a low $\mathrm{K}: \mathrm{Mg}$ ratio in soil. If the ratio is higher than $3: 1$, fertilization with potassium does not increase crop yields [FоTYMA et al. 1987]. In the bottom sediments collected from the two investigated reservoirs, the $\mathrm{K}: \mathrm{Mg}$ ratio was close to optimal. In Brody Iłżeckie, the $\mathrm{K}: \mathrm{Mg}$ is in the range 1.16-2.94, and in Zalew Zemborzycki, it ranged from 0.94 to 1.27.
In the sediments from Brody Iłżeckie, the ratio of potassium to the sum of calcium and magnesium ranged from 0.17 to 0.70 . A slightly wider ratio was observed in the sediments of sector VI. In the sediments from Zalew Zemborzycki, the discussed ratio was very low, not exceeding 0.1 . In both reservoirs, the ratio of potassium to the sum of calcium and magnesium was similar and did not indicate an increase in the potassium content in relation to calcium and magnesium.

In the bottom sediments of both water reservoirs only the $\mathrm{K}: \mathrm{Mg}$ ratio was optimal. The mass ratios of $\mathrm{Ca}: \mathrm{Mg}$; $\mathrm{Ca}: \mathrm{K}$ and $\mathrm{K}:(\mathrm{Ca}+\mathrm{Mg})$ in the bottom sediments of Zalew Zemborzycki diverged considerably from the optimum ratios, due to the high $\mathrm{Ca}$ content.

When used in the natural environment/agriculture, the sediments studied should be supplemented with potassium and magnesium fertilizers. This, however, cannot be the only one criterion for classifying bottom sediments as useful for natural, including agricultural use. In addition, it is particularly important to pay attention to the content of xenobiotics, in this organic compounds, which was not the subject of the presented studies.

\section{CONCLUSIONS}

1. Bottom sediments collected from the investigated reservoirs differed in terms of the content and spatial distribution of the individual elements:

- the bottom sediments from Zalew Zemborzycki contained higher amounts of calcium, magnesium, and potassium compared to those from Brody Iłżeckie;

- the concentrations of the investigated macronutrients in bottom sediments of Brody Iłżeckie and Zalew Zemborzycki can be arranged in the following decreasing order: $\mathrm{Ca}>\mathrm{K}>\mathrm{Mg}>\mathrm{Na}$;

- sediments sampled from different sampling points of the Brody Iłżeckie reservoir had different contents of calcium, magnesium, potassium, and sodium; sediments from sectors VI and VII (near the dam) had higher contents of all of those elements; in the case of Zalew Zemborzycki, the contents of $\mathrm{Ca}, \mathrm{Mg}, \mathrm{K}$ and $\mathrm{Na}$ tended to be higher in bottom sediments found in the lower part of the reservoir (sector D).

2. The ratios of the $\mathrm{K}: \mathrm{Mg}$ and $\mathrm{K}:(\mathrm{Ca}+\mathrm{Mg})$ were similar in the sediments of both reservoirs, and $\mathrm{Ca}: \mathrm{Mg}$ and $\mathrm{Ca}: \mathrm{K}$ slightly more favourable in the sediments of Brody Iłżeckie. When the sediments in the natural environment/agriculture are used, it is advisable to supplement them with potassium and magnesium fertilizers, but this is not the only one criterion for classifying bottom sediments for natural/agricultural use.

\section{Acknowledgements}

Publication financed by the Ministry of Science and Higher Education's budget for education under project No. N N305 410238. 


\section{REFERENCES}

Baran A., Jasiewicz Cz., Tarnowski M. 2009. Wpływ zbiornikowego osadu dennego na zmiany właściwości fizykochemicznych gleby lekkiej [Effect of bottom sediments from the Besko reservoir on yield and content of macroelements in maize biomass]. Proceedings of ECOpole. T. 3. Nr 2 p. 403-408.

Bojakowska I., Gliwicz T., MaŁecka K. 2006. Wyniki geochemicznych badań osadów wodnych Polski w latach 2003-2005 [Results of geochemical studies of Poland's water sediments in 2003-2005]. Biblioteka Monitoringu Środowiska. Warszawa. IOŚ. ISBN 8372172846 pp. 147.

CHOIŃSKi A., DiATTA J.B., ŁaWNiCZAK A. 2010. Ocena stanu zanieczyszczenia $\mathrm{Cu}, \mathrm{Zn}, \mathrm{Pb}$ i Cd osadów dennych Jeziora Niepruszewskiego. W: Woda w badaniach geograficznych [Evaluation of the state contamination of the Niepruszewskie Lake's sediments with $\mathrm{Cu}, \mathrm{Zn}, \mathrm{Pb}$ and Cd. In:Water in geographical studies]. Eds. T. Ciupa, R. Kuligowski. Kielce. UJK p. 159-167.

Fotyma M., Mercik S., FABer A. 1987. Chemiczne podstawy żyzności gleb i nawożenia [Chemical basis for soil fertility and fertilization].Warszawa. PWRiL. ISBN 8309011172 pp. 319.

GAŁKA B., WiATKOWSKi M. 2010. Charakterystyka osadów dennych zbiornika zaporowego Młyny oraz możliwość rolniczego ich wykorzystania [Characteristics of bottom sediments of retention reservoir Młyny and a possibility of their agricultural use]. Woda-Środowisko-Obszary Wiejskie. T. 10. Z. 4(32) p. 53-63.

KIEPUL J. 2003. Wpływ różnych zabiegów odkwaszających na plonowanie roślin i właściwości gleby [Influence of various deacidification measures on crop yields and soil properties]. Zeszyty Problemowe Postępów Nauk Rolniczych. Z. 493 p. 629-635.

MADEYSKI M., TARNAWSKI M. 2007. Wstępna ocena ilości i jakości osadów dennych wydzielonej części zbiornika wodnego „Besko” na rzece Wisłok [Preliminary qualitative and quantitative evaluation of bottom sediments of the side part of the storage reservoir „Besko” on the river Wisłok]. Infrastruktura i Ekologia Terenów Wiejskich. Nr 4. Cz. 1 p. 101-110.

Mercik S. (ed). 2004. Chemia rolna. Podstawy teoretyczne i praktyczne [Agricultural chemistry. Theoretical and practical basics]. Warszawa. Wydaw. SGGW. ISBN 837244-285-1 pp. 288.

Niedźwiecki E., Wojcieszczuk T., Poleszczuk G., MelLeR E., MALinowski R., SAmmel A. 2007. Skład chemiczny osadów dennych zbiorników wodnych Rusałka i Słoneczna Aglomeracji Szczecińskiej i możliwości ich wykorzystania [Chemical composition of bottom sediments in water reservoirs "Rusałka” and „Słoneczne” located within the area of Szczecin municipality and the possibilities of their utilisation]. Zeszyty Problemowe Postępów Nauk Rolniczych. Z. 520 p. 353-362.
RAFAŁOWSKA M., SobCZYŃSKA-WóJCIK K. 2014. Akumulacja materii w osadach dennych Zatoki Pilwa (Jezioro Dobskie) pod wpływem intensywnej produkcji rolnej [The effect of intensive agricultural production on organic matter accumulation in the bottom deposits of Pilwa bay (Lake Dobskie)]. Proccedings of ECOpole. T. 8. Nr 1 p. 261-266.

SAMmel A. 2015. Skład chemiczny osadów dennych zbiorników wodnych Syrenie Stawy aglomeracji szczecińskiej i możliwości ich wykorzystania [Chemical composition of bottom sediments of water reservoirs Syrenie Stawy located within the area of Szczecin municipality and possibilities of their utilisation]. Zeszyty Naukowe Uniwersytetu Zielonogórskiego. Z. 157. Inżynieria Środowiska. Nr 37 p. 53-60.

SKWIERAWSKI A. 2003. Skład chemiczny osadów dennych małych zbiorników wodnych jako odzwierciedlenie nasilenia procesów antropopresji w krajobrazie rolniczym [Chemical composition of bottom sediments of small water reservoirs as the reflection of anthropopressure processes in agricultural landscape]. Chemia i Inżynieria Ekologiczna, T. 10. S1 p. 159-169.

SMAL H., LigęZA S., BARAN S. 2012. Odczyn i właściwości sorpcyjne osadów dennych Zalewu Zemborzyckiego i zbiornika Brody Iłżeckie [Reaction and sorptive properties of bottom sediments of Zalew Zemborzycki and Brody Iłżeckie reservoirs]. Inżynieria Ekologiczna. $\mathrm{Nr}$ 29 p. 174-181.

SMal H., Ligęza S., Baran S., Wójcikowska-Kapusta A. 2015. Quantity and quality of organic carbon in bottom sediments of two upland dam reservoirs in Poland. Environment Protection Engineering. Vol. 41. No. 1 p. 95110.

TARNAWSKI M., BARAN A., JASIEWICZ CZ. 2012. Ocena właściwości fizyczno-chemicznych osadów dennych zbiornika Chańcza [Assessment of physicochemical properties of the bottom sediments Chańcza reservoir]. Proceedings of ECOpole. T. 6. Nr 1 p. 305-311.

Trojanowski J., ANTONOWicz J. 2005. Właściwości chemiczne osadów dennych jeziora Dołgie Wielkie [Chemical characteristics of bottom sediments in Dołgie Wielkie Lake]. Słupskie Prace Biologiczne. $\mathrm{Nr} 2$ p. 123-133.

TURSKi R., MisZTAL M., SMAL H. 1985. Wpływ gospodarki w zlewni Bystrzycy na skład chemiczny jej osadów dennych [The impact of the management in the Bystrzyca catchment on the chemical composition of its bottom sediments]. Annales UMCS. Sectio B. Vol. 11 p. $209-218$.

Wiśniowska-Kielian B., Arasimowicz M., Niemiec M. 2012. Post-effect of bottom sediment addition to the substratum on chemical composition of white mustard (Sinapis alba L.) biomass. P. 2. Quantitative ratios between macroelements. Ecological Chemistry and Engineering. Ser. A. T. 19. Z. 4-5 p. 387-393. 


\section{Anna WÓJCIKOWSKA-KAPUSTA, Halina SMAL, Sławomir LIGĘZA}

Zawartość niektórych makroelementów w osadach dennych dwóch zbiorników wodnych i ocena ich przydatności do przyrodniczego wykorzystania

\section{STRESZCZENIE}

Celem pracy była analiza zawartości wapnia, magnezu, potasu i sodu w osadach dennych dwóch zbiorników wodnych. Ocena składu chemicznego oraz stosunków pomiędzy badanymi makroelementami, uwzględniającymi wymagania żywieniowe roślin, były podstawą do określenia przydatności do przyrodniczego/rolniczego wykorzystania osadów dennych. Zadania prowadzono na dwóch obiektach - zbiorniku Brody Iłżeckie, w województwie świętokrzyskim, zbudowanym na rzece Kamienna, oraz Zalewie Zemborzyckim na rzece Bystrzycy, w województwie lubelskim. Oba zbiorniki pełnią funkcje przeciwpowodziowe i rekreacyjne, są też w niewielkim stopniu wykorzystywane przez przemysł. Są podobne pod względem wieku i powierzchni. Osady denne pobrano jednorazowo - 14 próbek z Zalewu Zemborzyckiego i 17 ze zbiornika Brody Iłżeckie. Analizowano w nich całkowitą zawartość Ca, Mg, K, Na. Osady denne z Zalewu Zemborzyckiego zawierały znacznie więcej wapnia, magnezu i potasu niż ze zbiornika Brody Iłżeckie. Stosunki analizowanych makroelementów były podobne (K:Mg; $\mathrm{K}:(\mathrm{Ca}+\mathrm{Mg})$ w osadach obu zbiorników lub nieco korzystniejsze $(\mathrm{Ca}: \mathrm{Mg} ; \mathrm{Ca}: \mathrm{K})$ w osadach zbiornika Brody Iłżeckie niż Zalewu Zemborzyckiego.

Słowa kluczowe: $\mathrm{Ca}, \mathrm{Mg}, \mathrm{K}, \mathrm{Na}$, osady denne, przyrodnicze wykorzystanie, zbiorniki wodne 